Original Research Paper

\title{
Nuclear Posture Review: Kahn Vs. Schelling....and Perry
}

\author{
${ }^{1}$ Timothy Sands, ${ }^{2}$ Harold Camacho and ${ }^{3}$ Richard Mihalik \\ ${ }^{1}$ Department of Mechanical Engineering, Stanford University, USA \\ ${ }^{2}$ Department of History, San Diego State University, USA \\ ${ }^{3}$ Department of Microbiology, University of Texas, USA
}

Article history

Received: 06-04-2018

Revised: 09-04-2018

Accepted: 27-04-2018

Corresponding Author:

Timothy Sands

Department of Mechanical

Engineering, Stanford

University, USA

Tel.: +1-831-656-3954

Email: dr.timsands@stanford.edu

\begin{abstract}
The 2018 American Nuclear Posture Review includes a revived emphasis on deployed, low-yield nuclear options to reserve credible deterrence against countries that have transmitted beliefs the U.S. would not respond to employment of non-strategic nuclear weapons, since there is a mistaken perception that the U.S. could only respond with high-yield strategic weapons, which would be deemed unacceptable. An important question to address is whether the Review increases the likelihood of American first-use of nuclear weapons or alternatively nuclear responses to provocations. This research briefly evaluates this development in light of the enduring theoretical debates in the literature concluding the possible potential to lower the threshold for first-use and responses with these weapons, while identifying active mitigation efforts. This sequel manuscript evaluates the Review in the context of classical theories of Kahn and Schelling, following the prequel comparisons to Waltz and Sagan. The implications both contextual analyses demand investigation of nuclear terrorism as recently espoused by former defense Secretary, now Stanford professor Bill Perry. This final analysis concludes this manuscript. Taken together, these first theoretical analyses initiate a modern nuclear debate in the literature.
\end{abstract}

Keywords: Low-Yield, Nuclear Posture Review, Escalation, De-Escalation, Rational Actor, Organizational Theory, Nuclear Deterrence

\section{Introduction}

Nuclear war is a horrific contemplation especially with our knowledge of nuclear weapon employment in World War II, followed by the development of weapons with staggering destructive capabilities that eclipsed many other factors in international relations for decades leading to a bi-polar world, where countries allied with major nuclear powers. Paradigms change with the natural passage of time and the occurrence of major world events, like the dissolution of the Soviet Union, or the recent resurgent Russia. These major events drive the formulation of national policies and one such major policy has just been published by the United States: The 2018 Nuclear Posture Review (NPR, 2018). Theories of international relations and conflict, particular theories on nuclear deterrence provide guiding windows through which we gaze upon the new nuclear posture review, which is clearly a reaction to a strategic mismatch in capabilities between the United States and other world power, Russia in particular (as it relevant to this investigation).

\section{Assertions and their Theoretical Context}

A key challenge of modern nuclear deterrence is the non-strategic nuclear capabilities of Russia. Figure 1, taken directly from the nuclear posture review pictorially reveals the mismatch and uses this mismatch as the backdrop of assertions that Russia believes limited nuclear first-use, particularly with low-yield weapons provides a deterrent advantage over the United States based in part on Moscow's perception that it a mismatch in non-strategic options provides coercive advantages at low-levels of conflict. Interestingly, two assertions are made...separated by only one paragraph. Firstly, it is asserted that the evolving Russian nuclear doctrine based in this mismatch lowers the threshold for their first-use of nuclear weapons and then secondly asserted is expanding U.S. low-yield, non-strategic nuclear capabilities will not lower the threshold of American first-use of 48 nuclear weapons.

How can both assertions be simultaneously true? Lowyield nuclear weapons either do, or do-not lower the threshold of first use. Perhaps a brief literature review can illuminate how both assertions might be simultaneously true. 


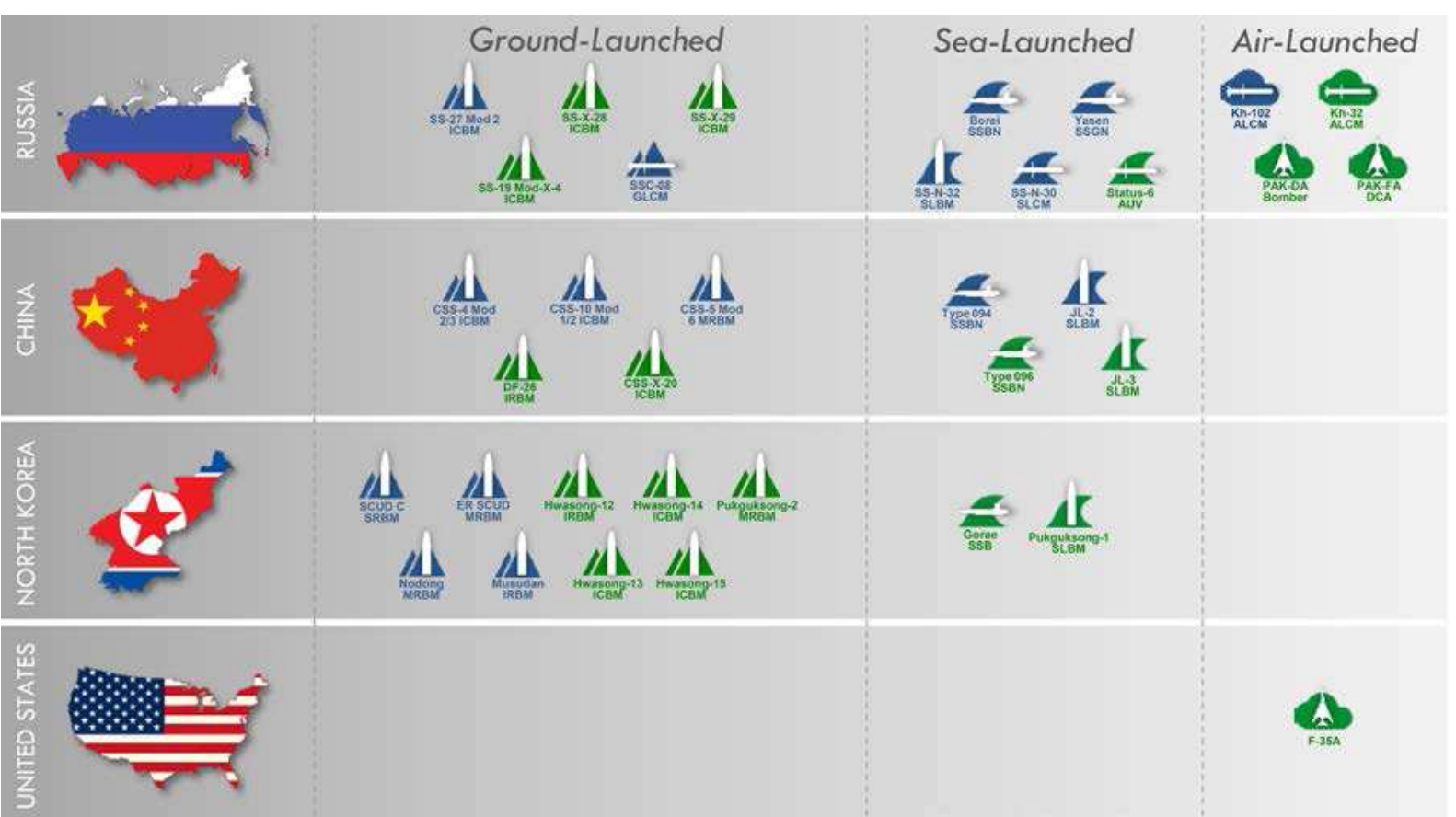

Fig. 1: The mismatch in capabilities: nuclear delivery systems developed since 2010

The mismatch displayed in Fig. 1 illustrates a long history of Russian emphasis on nuclear weapons to achieve its national security objectives (Paret et al., 1986), but furthermore illustrates that Russia, China and North Korea have dramatically outpaced the U.S. in nuclear weapon developments since 2010 (Nakatani and Sands, 2018a). The figure reveals strong nuclear weapon developments in those three countries have not been matched and the NPR does not imply the need to seek parity. What's left unanswered is how the new emphasis on American low-yield nuclear weapons amidst this imbalance sits in the body of classical theories of nuclear deterrence, escalation and proliferation. The prequel research (Sands, 2018) evaluated the NPR in the context of contending theories of Waltz' rational actor theory (Waltz, 1981) and Sagan's organizational theory of nuclear deterrence (Sagan, 1994), while the literature review here continues with Kahn (escalation dominance theory) and Schelling (uncertain threat theory).

\section{Literature Review: Escalation Dominance Versus Uncertain Threat Theories of Escalation}

As described in (Elkus, 2009), in his essay "The First Two Generations of Nuclear Strategists," Lawrence Freedman (Freedman, 1986) divides nuclear strategic thinking into two camps: Kahn and Schelling. Their respective intellectual approaches to nuclear strategy diverge on the question of whether nuclear warfare can be controlled. Kahn theorized nuclear war was indeed controllable, while Schelling, an economist who wrote on nuclear strategy, had a different idea of deterrence; instead advocating making the enemy fear the process getting out of control.

\section{Escalation Dominance Theory by Herman Kahn}

Theorems in this section derive from (Kahn, 2009) and are paraphrased for brevity and ease to the reader.

\section{Theorem 1}

Escalation dominance theory: Intimidation with the fear of the unknown. Nuclear warfare could be controlled by the political authority right up to the apocalyptic "spasm war" climax by domination of the conceptual ladder with forty-four various "rungs" of both nuclear and non-nuclear escalation beginning with an ostensible crisis in the first tier of three rungs called "subcrisis maneuvering" and culminating with spasm or insenate war at the pinnacle of the top tier of rungs called "civilian central wars".

\section{Uncertain Threat Theory by Thomas Schelling}

With game theory as a unifying framework for the social sciences, a party can strengthen its position by overtly worsening its own options, that the capability to retaliate can be more useful than the ability to resist an attack and that uncertain retaliation is more credible and more efficient than certain retaliation. Theorems in this section derive from (Schelling, 1981) and are paraphrased for brevity and ease to the reader. 


\section{Theorem 2}

Violence is a fundamentally chaotic and emotional activity. Even in a so-called limited war between nuclear powers things risked getting out of control. An uncertain threat had more credibility than a stated one. Letting a situation intentionally degrade drives an adversary to conclude that it would be better to turn away from the brink once the situation appeared dangerous and unpredictable.

\section{Proofs of Theorems: Kahn and Schelling}

It is ubiquitously argued in the literature that neither Kahn's nor Schelling's theories were ever tested, but consider the Cuban missile crisis as a nuclear one where the United States allowed the situation degrade and then passively awaited capitulation of the Soviet Union, while the Soviets were forced to decide on a proper course of action in an environment of uncertainty in the face of the bold threats of the U.S. president.

\section{Discussion}

Rather than repeat the analysis of Kahn vs. Schelling in the context of "who's right?", the authors instead utilize theoretical elements of both scholars seeking commentary on the just-published American nuclear posture review.

\section{Implications of the Literature Review}

The review of the nuclear posture review against the backdrop of the theoretical literature commenced in (Sands, 2018) with an examination of the review in the context of competing theories of Waltz and Sagan seeking to comment on whether the literature supports the notion the NPR implies an increasing or decreasing likelihood of an American first-use of nuclear weapons due to its emphasis on low-yield weapons. Waltz theories are referred to as rationale actor theory; while Sagan purported bureaucracies (especially the military) has inherent aberrant behaviors that must be account for (i.e., irrational, yet explainable behaviors). (Sands, 2018) postulates, "in light of these two theories, the future holds at best, no-change in the threshold of first-use of nuclear weapons, as is the case with the rational actor theory; or at worst an increased likelihood of American first use in instances where a targeted nation has no strong alliance with Russia."

In the context of escalation dominance theory of Kahn, increased American emphasis in the nuclear posture review on the development of some (not seeking parity) low-yield capabilities does not necessarily incentivize global thermonuclear war, particularly since parity is not sought and thus superiority in number is unlikely. Kahn's theory suggests that addition of low-yield nuclear weapons increases the American ability to dominate escalation by providing incremental responses to low-yield nuclear use by adversaries. Thus, whilst not specifically incentivizing global nuclear war, the NPR's emphasis on low-yield weapons does increase the likelihood of an American nuclear response to crises around the world in attempts to manage (and dominate) escalation where conflict resolution occurs under favorable condition to the U.S..

The context of uncertain threat theory by Schelling further reinforces the likelihood of American use of lowyield nuclear weapons in response to crises, since it retains the ability to escalate while increasing the uncertainty of adversary nations: Will American massively respond, or perhaps use low-yield weapons instead? Thus, unlike the prequel (Sands, Mihalik, Camacho, 2018) where the contending theories yielded slightly different implications, the theories investigated here by Kahn and Schelling both seem to indicate an increased likelihood of America using low-yield nuclear weapons to manage (dominate) escalation and increase the adversaries uncertainty in potential American responses to provocation.

\section{The World Following Publication of the Nulcear Posture Review}

In light of these four theories, the future holds at best, no-change in the threshold of first-use of nuclear weapons, as is the case with the rational actor theory; or at worst an increased likelihood of American first use in instances where a targeted nation has no strong alliance with Russia. Yet both Escalation Dominance theory and the theory of Uncertain Threat indicate an increased likelihood of and American nuclear response.

In light of the failures seen at the 2010 and 2015 nuclear nonproliferation treaty review conferences (Sands and Mihalik, 2016a), proliferation concern is increased by an increase in development of small-yield tactical nuclear weapons in America, where relative freedom accompanies increased risk of scientist and engineers involved in those efforts becoming proliferation risks themselves (e.g., through technology transfer).

Another complicating factor is the admission that the United States has found itself preoccupied for many years with the Middle East, most recently with the Islamic State (Sands, 2016). It begs the question "is the next generation of Americans prepared to go down this path of increased tactical nuclear options?" Seemingly in answer to the question, the U.S. Air Force has already begun an earnest effort to increase the critical thinking capabilities of its nuclear enterprise (Sands et al., 2017) vis-à-vis rigorous education programs available part-time, using distance learning technologies to educate increasingly larger portions of the air force's nuclear members.

\section{Nuclear Terrorism: What would Bill Perry think?}

Former U.S. Secretary of Defense Bill Perry now teaches an open, online course at Stanford University 
(Perry, 2017), "The Threat of Nuclear Terrorism" articulating five key questions:

1. Who Are the Terrorists What Do They Want?

2. What Are the Historical and Contemporary Security Issues with Nuclear Weapons and Materials?

3. Could a Terrorist Group Make Its Own Nuclear Bomb?

4. What are the consequences of an Improvised Nuclear Device's Detonation in a U.S. City?

5. What Can Be Done?

The NPR addresses the issue of nuclear terrorism in two manners. First, the NPR addresses the issue of preventing terrorists from obtaining and employing nuclear material by employing a layered defense in depth highlighted by (1) securing nuclear weapons, materials, related technology and knowledge; (2) enhancing collaboration with allies, partners and international institutions; (3) employing advanced forensics and attribution capabilities to deter state support for nuclear terrorism; (4) strengthening defenses; and (5) enhancing preparedness to mitigate nuclear incident effects. The second manner in which the NPR addresses the terrorist issue is to reemphasize the US policy of holding accountable any state, terrorist group or other non-state actor that supports or enables terrorist efforts to obtain or employ a nuclear device (note that the NPR does not distinguish between the use of a Radiation Dispersal Device (RDD), Improvised Nuclear Device (IND) or full up nuclear weapon) and that such use would constitute an "extreme circumstance" that would call for the US to consider the ultimate form of retaliation. One issue that this later statement has is actually determining who or what entity is responsible and should therefore feel the wrath of the United States-would it be the terrorist group itself, the state sponsor of the terrorist group (what if there is more than one state sponsoring the group's activities?), or the state in which the terrorist group built its device, what about the middle-men involved in getting the device to its target; or the financial entity (ies) who enabled the terrorist group to obtain the needed materials? What would be the proportional response to such an attack?

Understanding the effects that would emanate from the detonation of a nuclear device-physical, psychological and economic are of paramount significance. There are a lot of myths, half-truths and downright misinformation when it comes to describing the ease with which a terrorist group could obtain such a device and in the effects of a nuclear detonation. Dr William Perry, in his on-line Nuclear Terrorism Course, introduces the course by relating to his students his nuclear nightmare where in a terrorist group is able to obtain fissile material, build a workable device, ship that device to the US where it is in turn put into the hands of a terrorist cell residing in the country, transported to a major US city and subsequently detonated. It paints a scary picture but tends to ignore, or at least play down significantly, the actual difficulties any would be terrorist would encounter in such a quest-difficulties related to obtaining the necessary materials; having the technical where withal (people and equipment) and unimpeded time and space needed to engineer the device into a useable and reliable weapon (the last thing any terrorist would want would be for their weapon to not function when called upon to do so-it makes for lousy optics); transporting the device to the target area undetected; and finally maintaining the secrecy within the group and any affiliated associates the group would need to reach its goal from the beginning of the effort through its final detonation.

Assuming that a terrorist group was able to obtain or develop a nuclear device, successfully transport it to the US and detonate it in or near a major metropolitan area what would be the effects? First and most obvious would be the effects created by the explosion itselfthese would of course are totally dependent on the size and location of the blast. Below are two hypothetical scenarios for consideration where a device similar in size to the 2013 North Korean nuclear warhead is sailed into San Francisco Bay striking a soft target such as the port in Redwood City (Fig. 2) or perhaps the mothball fleet (Fig. 5) in the northeastern bay city of Suisun. The figures are produced using a nuclear weapons' effects simulation that is taught as part of Dr. Perry's course at Stanford mentioned above. The simulation is called NUKEMAP and it was developed by Alex Wellerstein (2018) which produced fig. 3-7.

Figure 3 depicts a notional detonation site in the Redwood City port, where the $10 \mathrm{kT}$ device is detonated while the boat is afloat in one of the waterways depicted. The result of the simulation is displayed in Fig. 3. Notice a "mere" 850 direct casualties from the blast and thermal effects of the detonation. Significant quantities of radiated water and earth would be dispersed over a wide area inflicting additional harm. Notice the far-reaching affects displayed in Fig. 4 downwind of the detonation (These simulations ignore the effects of nuclear fallout which would be significant since the detonation is a "ground burst"). Despite a seemingly immediate and or direct low count of casualties for a "nuclear strike", next consider the psychological effect on San Francisco, San Jose, California in general and the nation at large.

However, terrorists might seek to intentionally do more damage by choosing a better location to detonate their $10 \mathrm{kT}$ weapon in order to create "visually pleasing level of destruction" for their supporters.

Consider a second potential hypothetical scenario, where the terrorist continues up-river to pull astride the "mothball fleet" docked in Suisun City (Fig. 6). Simulation results (again neglecting the effects of fallout) are displayed in Fig. 7. Significantly more causalities (over 10,000) result from such a detonation in addition to the pronounced statement of inflicting damage to the capital city of California. Thus we see the fear of such a strike is real. 


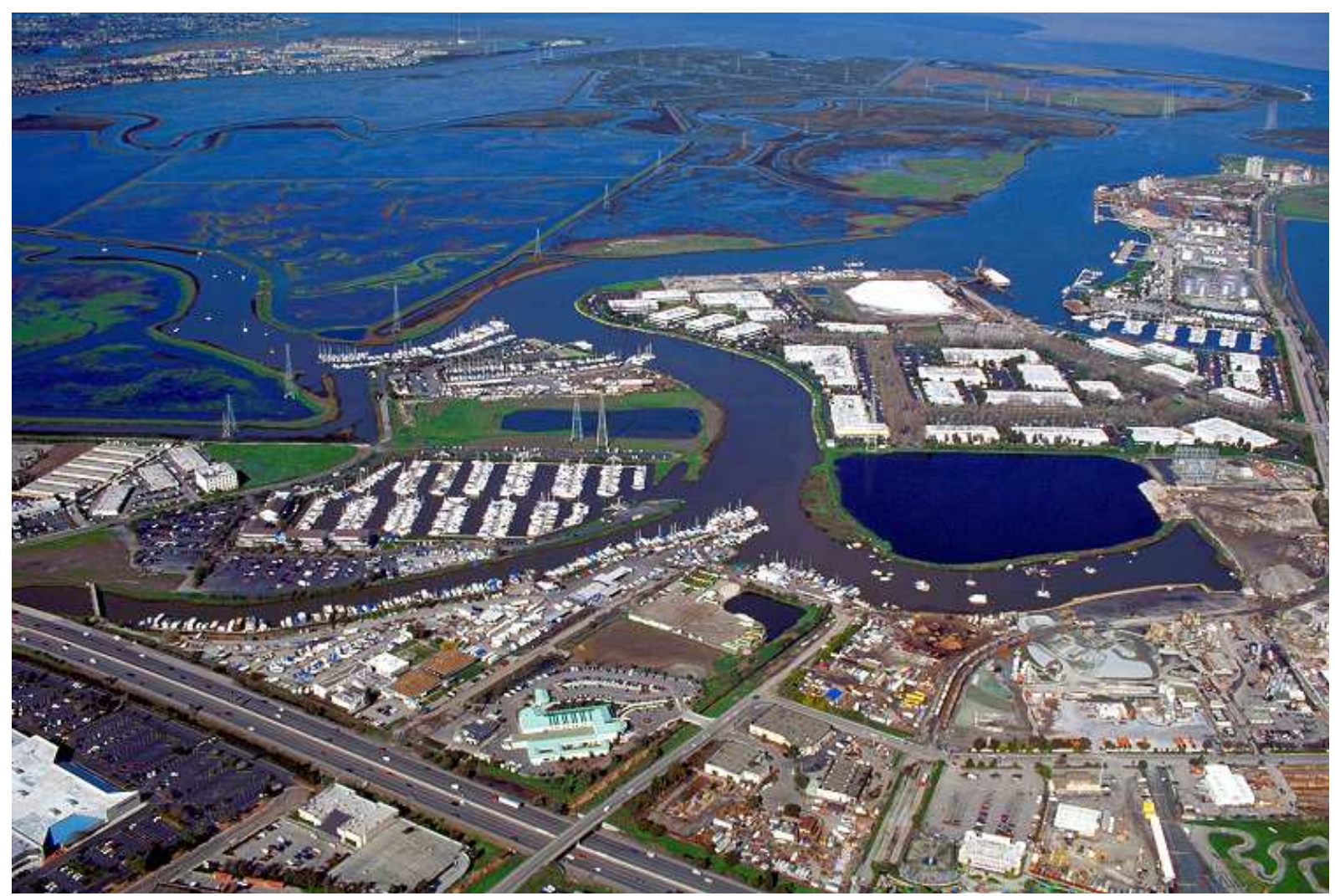

Fig. 2: Soft target: Redwood City Port, just north of San Jose, California. Taken from (Wikipedia, 2018)

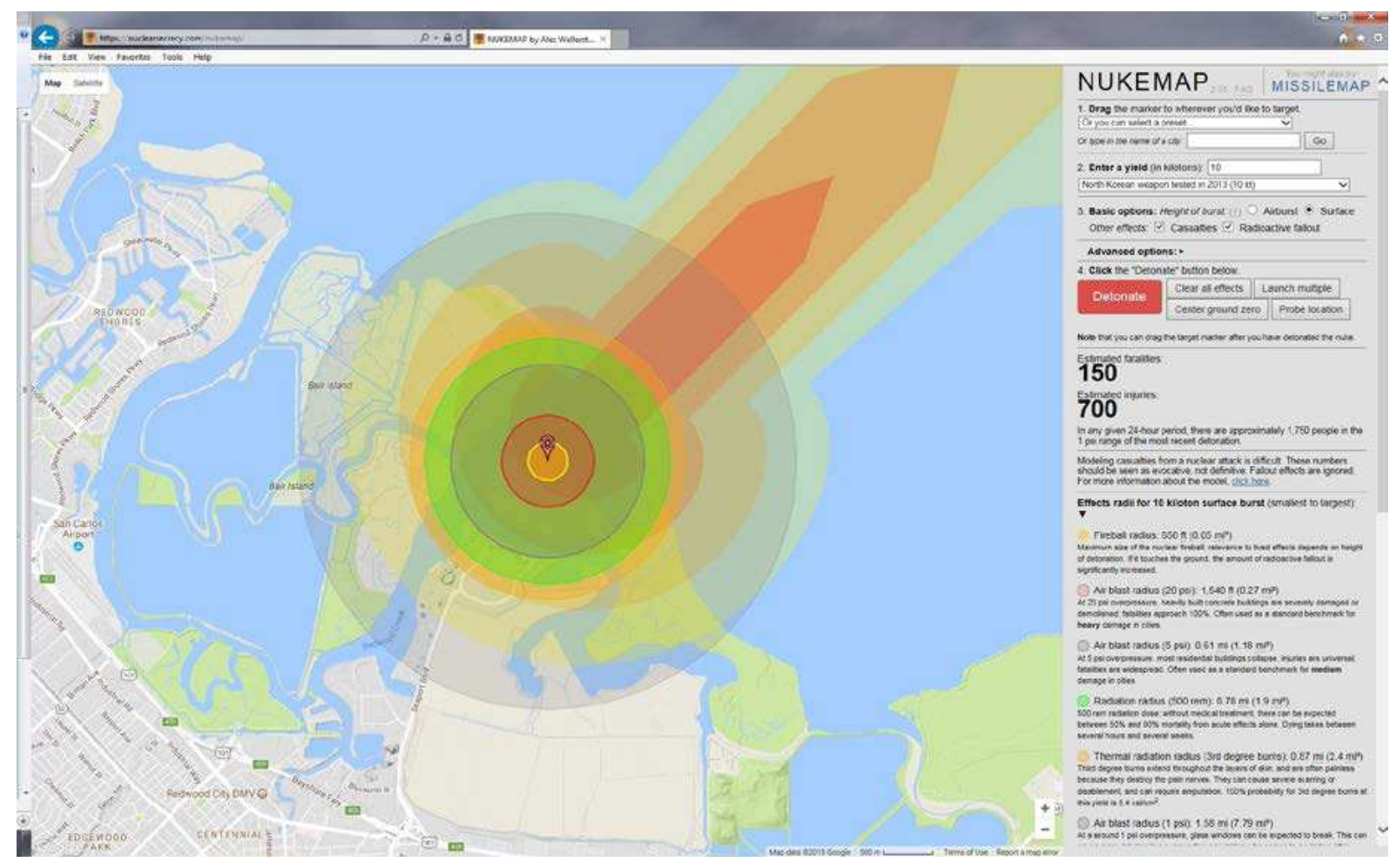

Fig. 3: Detonation at Redwood City Port, just north of San Jose, California 


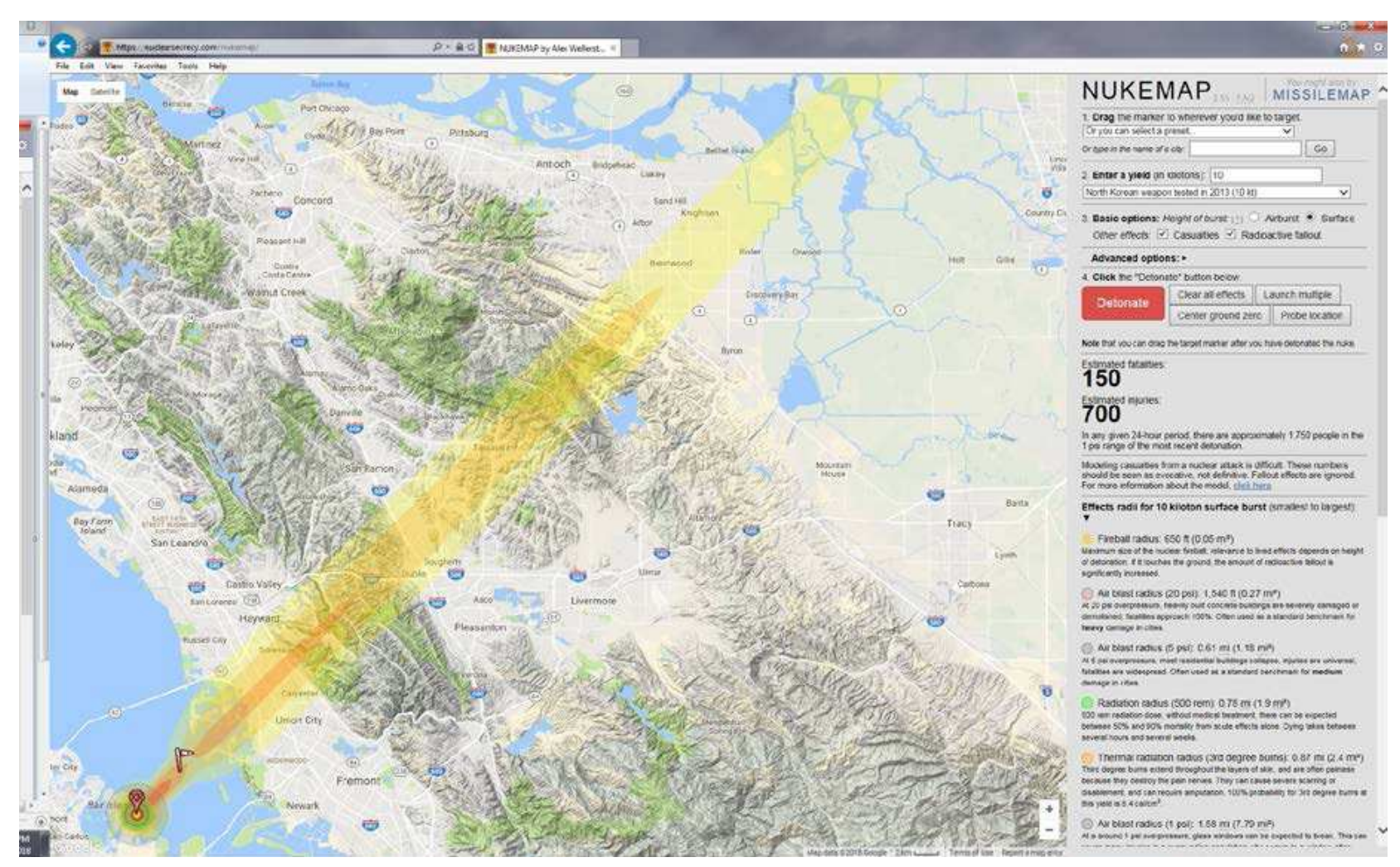

Fig. 4: Downwind Redwood City Port, just north of San Jose, California

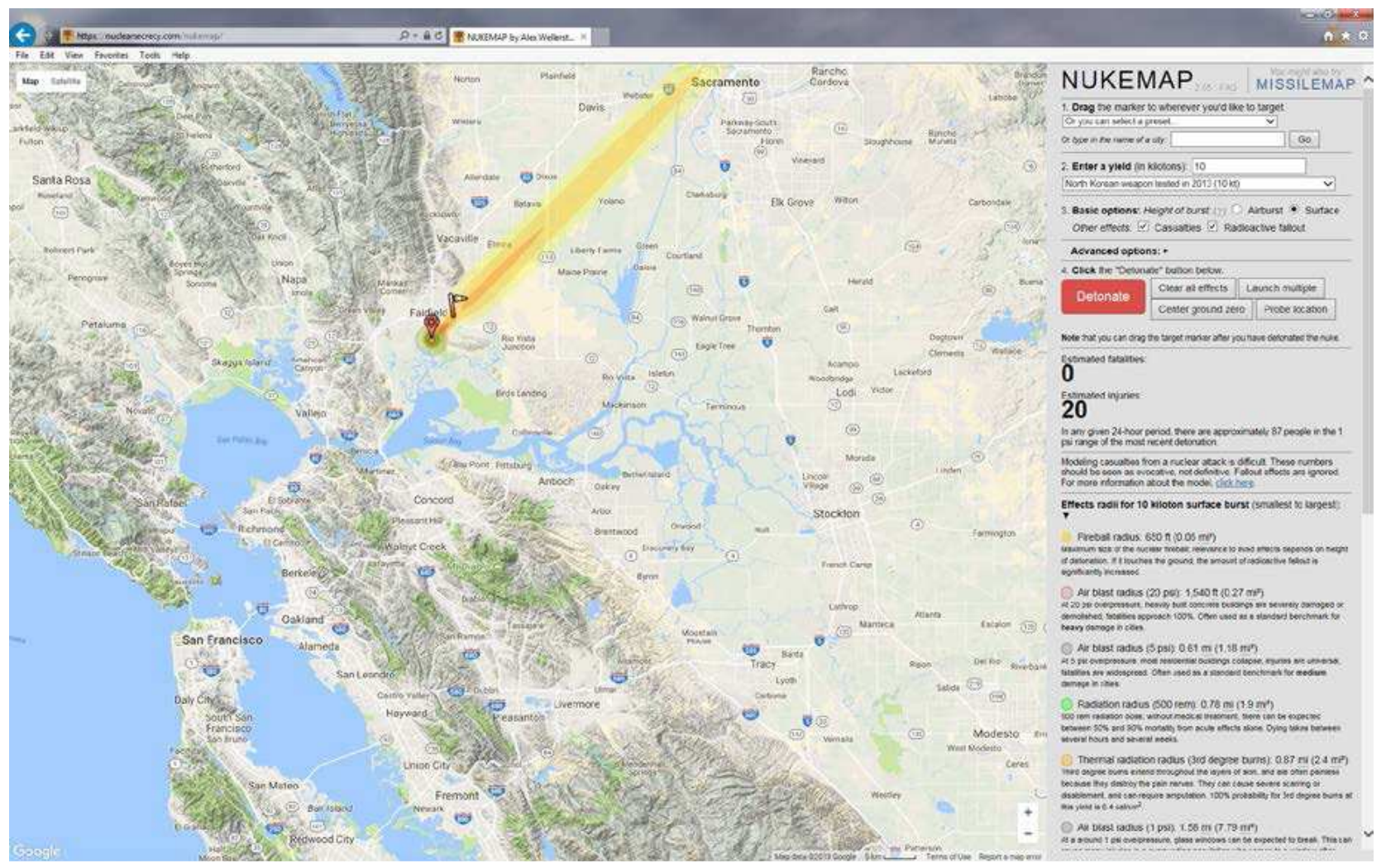

Fig. 5: Enroute Suisun City, northeast of San Francisco Bay 


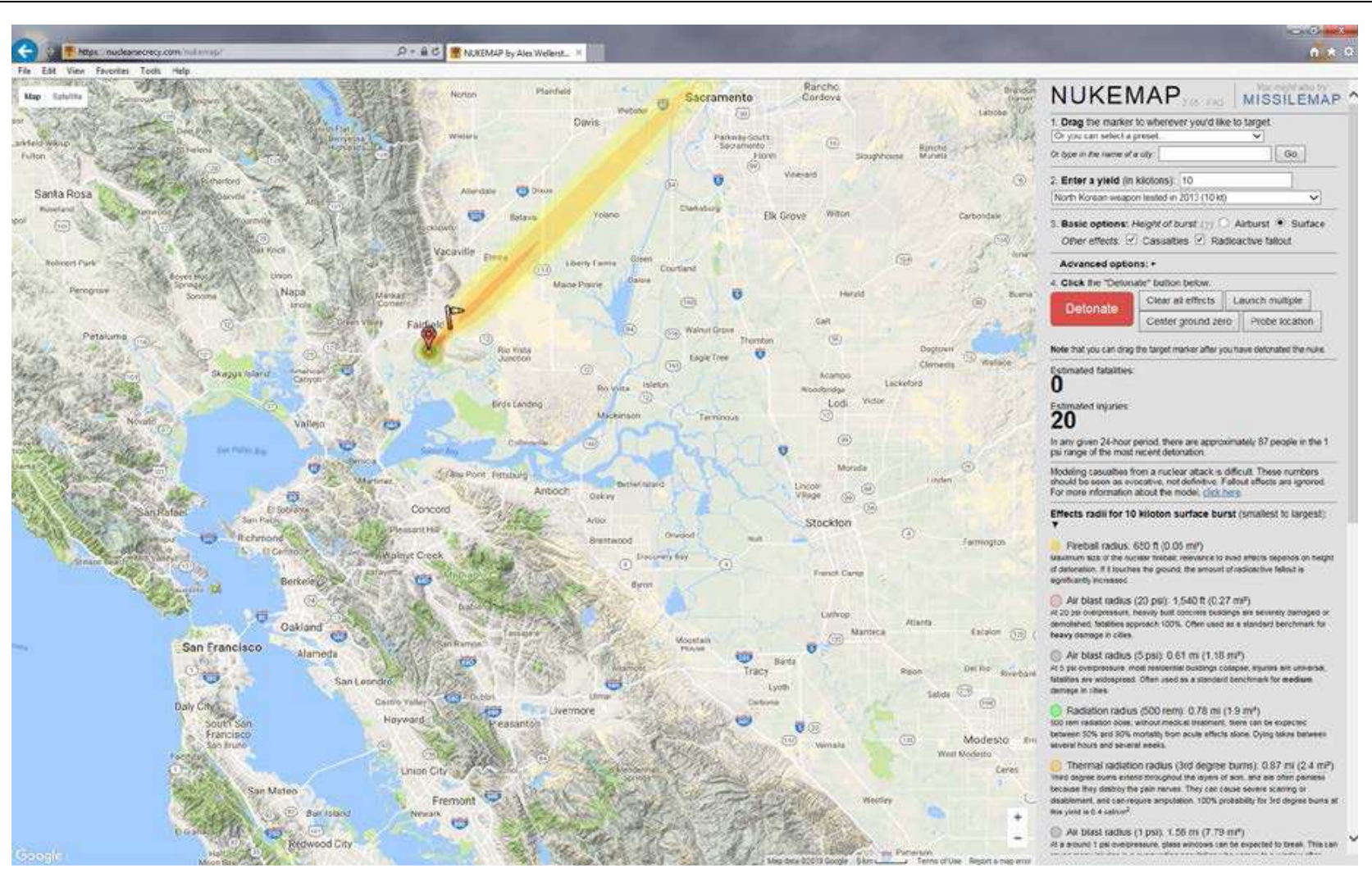

Fig. 6: Suisun City docks, northeast of San Francisco Bay

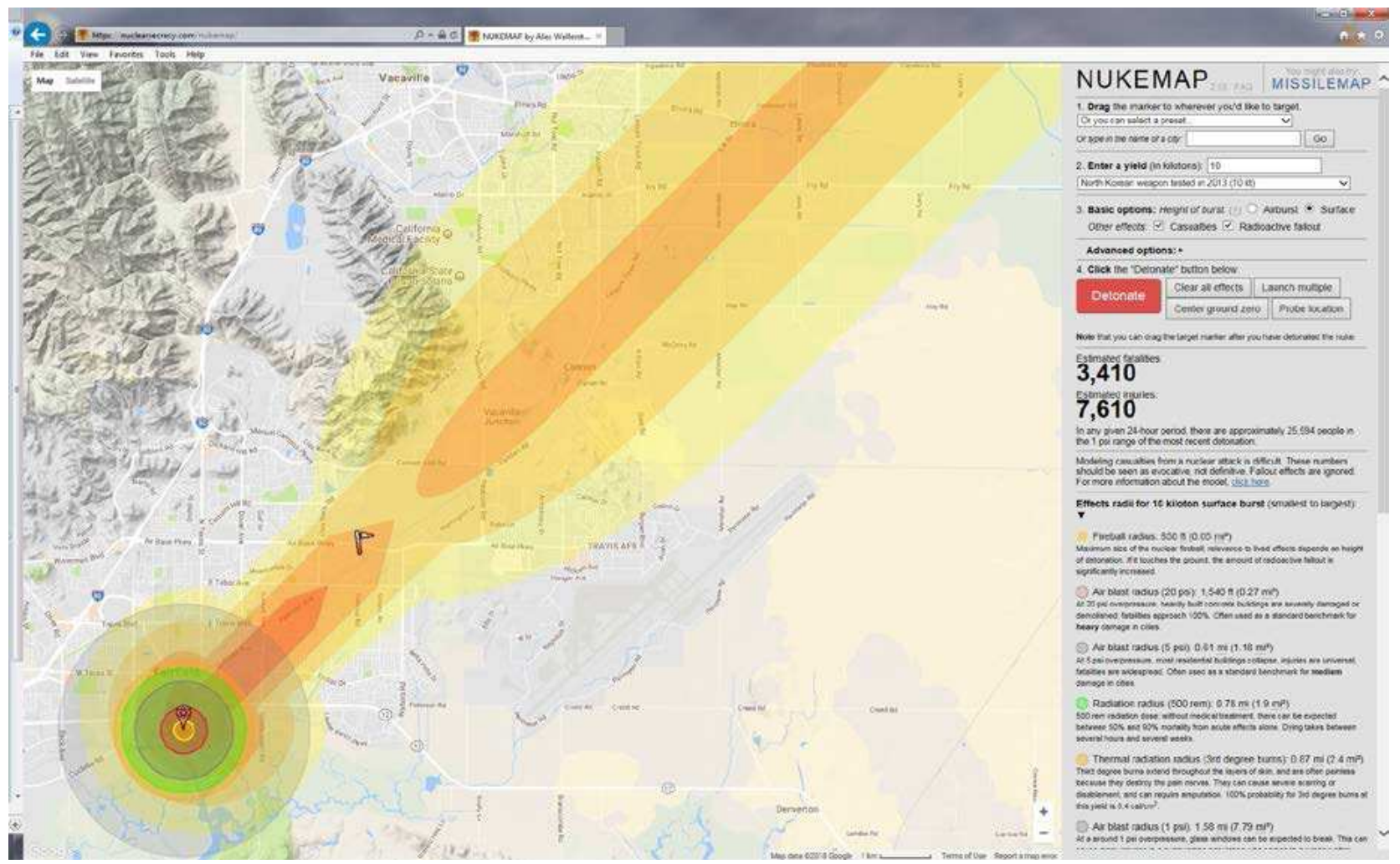

Fig. 7: Detonation of 10kT device at Suisun City docks, northeast of San Francisco Bay 
Aside from the direct effects related to the physical damage caused by blast, thermal radiation and ionizing radiation resulting from the detonation of such a device in a metropolitan area, there would also be significant psychological effects resulting from the mere fact of the detonation, these would most likely be felt well outside of the immediate area of the blast and very likely would encompass most of the country. Added to this would be the effects of the potential collapse of the city's response capability-hospitals unable to handle the casualties due to loss of power, doctors, etc. and the panic of the population creating traffic problems and increased exposure to fallout. These effects would be both immediate and long term as the radiation-related illness begins to take effect. Lastly, economic impacts would begin to be felt due to breakdowns in supply chain operations as well as due to workers being unable to reach places of employment due to evacuations, loss of infrastructure, or destruction of work place, or illness related to radiation exposure.

While the probability of a terrorist group detonating a nuclear weapon or device may be "low" the risk of such an event would be considered "high" (Arguello, 2016) and therefore it is imprudent on our part to be complacent. The NPR rightfully gives the threat it's due and provides a sound approach to dealing with this issue. One could argue that the NPR's emphasis's on the re-introduction and deployment of a low-yield capability via a low yield SLBM delivered weapon or SLCM, would give the U.S. the means and ability to respond within the principle of proportionality and within the laws of armed conflict in the event such a device were ever to be detonated within the US or against an ally or partner and in a timely manner but also serves to put on notice potential enablers. As pointed out in (Bunn and Roth, 2017), "the idea of terrorists accomplishing such a thing is, unfortunately, not out of the question: it is far easier to make a crude, unsafe, unreliable nuclear explosive that might fit in the back of truck than it is to make a safe, reliable weapon of known yield that can be delivered by missile or aircraft...."

\section{American Prepardness to Implement the Guidance in the New NPR}

A complicating factor is the admission that the United States has found itself preoccupied for many years with the Middle East, most recently with the Islamic State (Sands, 2016). It begs the question "is the next generation of Americans prepared to go down this path of increased tactical nuclear options?" Seemingly in answer to the question, the U.S. Air Force has already begun an earnest effort to increase the critical thinking capabilities of its nuclear enterprise (Sands et al., 2017) vis-à-vis rigorous education programs available part-time, using distance learning technologies to educate increasingly larger portions of the air force's nuclear members. These new education programs are designed to expose nuclear forces to the theorems and proofs presented in this manuscript in accordance with a new education paradigm described in paragraph 3.1 in (Mihalik et al., 2017). Professor Sagan's course is specifically included on the list of available courses (Sands and Mihalik, 2016). In addition to the arguments in the social sciences, the air force is reinvigorating scientific education efforts towards all military missions in and through space (Nakatani, 2018; Sands, 2018; Kim et al., 2007; Nakatani, 2016; Sands, 2009) including nuclear systems. This undertaking requires significant refocusing towards recent technical developments (Sands and Lorenz, 2009; Sands, 2012; Cooper et al., 2017; Nakatani and Sands, 2018b, 2014; Sands and Kenny, 2017; Sands and Armani, 2018; Sands, 2017a, 2017b, 2017c, 2018a) the critical thinking ability of American nuclear forces. One particular area of emphasis is the technology to maneuver reentry warheads (Agrawal, et al., 2017), (Sands et al., 2006; 2007; 2009, 2012; 2016; 2018a) to avoid missile defenses (Sands et al., 2018b).

\section{Conclusion}

In light of two competing theories (Waltz vs. Sagan) and two complementary theories (Kahn and Schelling), the American declaration to increase its utilization of low-yield nuclear weapons to meet its deterrence objectives has the possible potential to lower the threshold for first-use of these weapons and likely increased potential for nuclear response. The increase is particularly troubling in the context of nuclear terrorism, but these potentials are being actively mitigated by current efforts to increase the critical thinking capabilities of the military members, possibly positioning them to avoid the organizational proclivities that might prevent fulfillment of the operational requirements for rational nuclear deterrence. Perry's theories emphasize nuclear terrorism and yield troubling concerns about proliferation. In light of the failures seen at the 2010 and 2015 nuclear nonproliferation treaty review conferences (Sands and Mihalik, 2016b), proliferation concern is increased by an increase in development of small-yield tactical nuclear weapons in America, where relative freedom accompanies increased risk of scientist and engineers involved in those efforts becoming proliferation risks themselves (e.g., through technology transfer).

Nonetheless, the U.S. seems to be taking the new NPR very seriously with accompanying resources allocated to many educational efforts in military and civilian universities. 


\section{Author Contributions}

Timothy Sands: Drafted manuscript; iterated content with co-authors and managed peer review.

Harold Camacho: Iterated content; particularly contributed sections on nuclear terrorism per [Perry].

Richard Mihalik: Inspired overall effort; provided senior mentorship; I terated content.

\section{Conflicts of Interest}

The authors declare no conflict of interest.

\section{References}

Agrawal, B., Kim, J., Sands, T., 2017, Method and apparatus for singularity avoidance for control moment gyroscope (CMG) systems without using null motion. US Patent 9,567,112.

Arguello, I., 2016. Terror unleashed, an assessment of global and national impacts of a nuclear terrorist attack. NPSGlobal Foundation.

Bunn, M. and N. Roth, 2017. The effects of a single terrorist nuclear bomb. Bull. Atom. Sci.

Cooper, M., P. Heidlauf and T. Sands, 2017. Controlling chaos-forced van der pol equation. Mathematics, 5: 70-80. DOI: $10.3390 /$ math5040070

Elkus, A., 2009. Kahn, schelling and paradoxical logic. Rethinking Security.

Freedman, 1986. The First Two Generations of Nuclear Strategists. 1st Edn., Clarendon Press, Oxford, ISBN-10: 0198200978.

Kahn, 2009. On Escalation: Metaphors and Scenarios. 1st Edn., New York, Routledge.

Kim, J., T. Sands and B. Agrawal, 2007. Acquisition, tracking and pointing technology development for bifocal relay mirror spacecraft. Proc. SPIE, 6569: 1-15. DOI: $10.1117 / 12.720694$

Mihalik, R., H. Camacho and T. Sands, 2017. Continuum of learning: Combining education, training and experiences. Education, 8: 9-13. DOI: $10.5923 /$ j.edu.20180801.03

Nakatani, S. and T. Sands, 2014. Simulation of spacecraft damage tolerance and adaptive controls. Proceedings of the Aerospace Conference, Mar. 1-8, IEEE Xplore Press, Big Sky, MT, USA, pp:1-16. DOI: 10.1109/AERO.2014.6836260

Nakatani, S., 2016. Autonomous damage recovery in space. Int. J. Automat. Contr. Intell. Sys., 2: 22-36.

Nakatani, S., Sands, T., 2018a, Eliminating the existential threat from North Korea. Science and Technology, ISSN: 2163-2677 8(2).

Nakatani, S., Sands, T., 2018b. Battle-damage tolerant automatic controls. Elec. Electr. Eng., 8: 10-23. DOI: $10.5923 /$ j.eee. 20180801.02
NPR, 2018. Office of the Secretary of Defense, Nuclear Posture Review. Washington, DC.

Paret, P., G. Craig and F. Gilbert, 1986. Makers of Modern Strategy from Machiavelli to the Nuclear Age. 1st Edn., Princeton University Press, Princeton, ISBN-10: 0691027641, pp: 941.

Perry, W.J., 2017. The threat of nuclear terrorism. Stanford University, Stanford, California.

Sagan, S.D., 1994. The perils of proliferation: Organization theory, deterrence theory and the spread of nuclear weapons. Int. Security, 18: 66-107. DOI: $10.2307 / 2539178$

Sands, T. and C. Armani, 2018. Analysis, correlation and estimation for control of material properties. J. Mechanical Eng. Automat. 8: 7-31. DOI: $10.5923 /$ j.jmea.20180801.02

Sands, T., 2016. Strategies for combating Islamic state. Soc. Sci., 5: 39-39. DOI: 10.3390/socsci5030039

Sands, T. and R. Mihalik, 2016. Outcomes of the 2010 and 2015 nonproliferation treaty review conferences. World J. Soc. Sci. Humanities, 2: 46-51. DOI: $10.12691 /$ wjssh-2-2-4

Sands, T. and T. Kenny, 2017. Experimental piezoelectric system identification, J. Mech. Eng. Automat., 7: 179-195. DOI: $10.5923 /$ j.jmea.20170706.01

Sands, T., 2009. Satellite electronic attack of enemy air defenses. Proceedings of the Southeast Conferecne, Mar. 5-8, IEEE Xplore Press, Atlanta, GA, USA, USA, pp: 434-438. DOI: $10.1109 /$ SECON.2009.5174119

Sands, T. and R. Lorenz, 2015. Improved magnetic levitation via online disturbance decoupling. Phys. J. 1: 272-280.

Sands, T., 2012. Physics-Based Control Methods. In: Advances in Spacecraft Systems and Orbit Determination, Ghadawala, R. (Ed.), InTech, London, pp: 2267-3121.

Sands, T., 2017a. Nonlinear-adaptive mathematical system identification. Computation, 5: 47-59. DOI: $10.3390 /$ computation5040047

Sands, T., 2017b. Space systems identification algorithms. J. Space Exp., 6: 138-149.

Sands, T., 2017c. Phase Lag Elimination at All Frequencies for Full State Estimation of Spacecraft Attitude, Physics Journal 3(1), 12.

Sands, T., 2018b. Experimental sensor characterization. J. Space Exploration, 7: 140.

Sands, T., H. Camacho and R. Mihalik, 2017. Education in nuclear deterrence and assurance. J. Defense Manage., 7: 166-166. DOI: $10.4172 / 2167-0374.1000166$.

Sands, T., J. Kim and B. Agrawal, 2012. Nonredundant single-gimbaled control moment gyroscopes. J. Guid. Dyn. Contr. 35: 578-587.

DOI: $10.2514 / 1.53538$ 
Sands, T., J. Kim and B. Agrawal, 2006. 2H singularity-free momentum generation with nonredundant single gimbaled control moment gyroscopes. Proceedings of the 45th Conference on Decision and Control, Dec. 13-15, IEEE Xplore Press, San Diego, CA, USA, pp: 1551-1556. DOI: $10.1109 /$ CDC.2006.377310

Sands, T., 2007. Fine Pointing of Military Spacecraft, Ph.D. Dissertation, Mechanical and Astronautical Engineering Department, Naval Postgraduate School, Monterey, CA, 2007.

Sands, T., J. Kim and B. Agrawal, 2009. Control moment gyroscope singularity reduction via decoupled control. Proceedings of the 45th Conference on Decision and Control, Dec. 13-15, IEEE Xplore Press, San Diego, CA, USA, pp: 1551-1556. DOI: 10.1109/SECON.2009.5174111

Sands, T., J. Kim and B. Agrawal, 2016. Experiments in control of rotational mechanics. Int. J. Automat. Contr. Int. Sys., 2: 9-22.

Sands, T., 2018a. Space mission analysis and design for electromagnetic suppression of radar. Int. J. Electromagnet. Applic., 8: 1-25.

DOI: $10.5923 /$ j.ijea.20180801.01
Sands, T., J. Kim and B. Agrawal, 2018a. Singularity Penetration with Unit Delay (SPUD). Mathematics, 6: 23-38. DOI: 10.3390/math6020023

Sands, T., D. Lu, J. Chu and B. Cheng, 2018b. Developments in angular momentum exchange. Int. J. Aero. Sci., 6: 1-6.

Sands, T., R. Mihalik and H. Camacho, 2018. Theoretical context of the nuclear posture review. J. Soc. Sci., 14: 124-128.

Schelling, T., 1981. The Strategy of Conflict. 1st Edn., Harvard University Press.

Waltz, K.N., 1981. The Spread of Nuclear Weapons: More May Better. Adelphi Papers, No. 171, International Institute for Strategic Studies, London.

Wikipedia website tiled "Port of Redwood City", https://en.wikipedia.org/wiki/Port_of_Redwood_City

Wellerstein, 2018. NUKEMAP simultation hosted by the College of Arts and Letters. Stevens Institute of Technology. 